\title{
ANALYSIS OF 13 TP53 AND WRAP53 POLYMORPHISM FREQUENCIES IN RUSSIAN POPULATIONS
}

Olkova MV1,2凶, Petrushenko VS², Ponomarev GYu²

${ }^{1}$ Research Centre of Medical Genetics (RCMG), Moscow, Russia

2 Vavilov Institute of General Genetics, Moscow, Russia

In the last decade the search for and annotation of human genome polymorphisms associated with phenotype have become particularly important concerning the opportunity of their use in medical and population genetics, pharmacogenomics and evolutionary biology. The study was aimed to calculate the frequencies and analyze the prevalence of 13 germline polymorphisms of two genes, TP53 encoding the genome-keeper p53 protein and WRAP53 involved in regulation of p53 production, in 28 Russian populations. We obtained data on 9 exonic TP53 variants (rs587781663, rs17882252, rs150293825, rs112431538, rs149633775, rs144340710, rs1042522, rs1800371, rs201753350), one intronic polymorphism (rs17881850), and three variants of WRAP53 (rs17880282, rs2287499, rs34067256). In the majority of populations the sample size was over 50 people (except five populations with 30-49 surveyed people). The alternative alleles' population frequencies for studies genetic variants in most Russian populations were close to appropriate allele frequencies in European and Asian populations of similar origin taken from global databases. The exceptions were six populations ("Central Caucasus", "Dagestan", "northern Russians", "southeastern Russians", "Tatars" and "Transcaucasia") with increased alternative alleles' population frequencies. All listed populations except the population of "southeastern Russians" are characterized by polymorphisms with high allele frequencies not satisfying the Hardy-Weinberg principle.

Keywords: p53, TP53, WRAP53, tumor marker, polymorphism, population frequency, genetic epidemiology

Acknowledgement: we would like to express our appreciation to Oleg Balanovsky, head of the Genome Geography Laboratory of the Vavilov Institute of General Genetics for study management and manuscript editing, to all DNA donors and Biobank of North Eurasia for provided collection of samples, as well as to the Center for Precision Genome Editing and Genetic Technologies for Biomedicine of the Pirogov Russian National Research Medical University (Moscow, Russia) for the opportunity to use the molecular biology technologies.

Funding: the study was carried out as part of the public contract between the Ministry of Science and Higher Education of the Russian Federation and the Research Centre of Medical Genetics (phenotyping of samples, database construction, data analysis).

Author contribution: Olkova MV — study design, statistical analysis, manuscript writing; Petrushenko VS — bioinformatics analysis, Ponomarev GYu — experiments.

Compliance with ethical standards: the study was carried out in accordance with the World Medical Association Declaration of Helsinki. All samples were obtained from Biobank of North Eurasia. The informed consent was obtained from all donors.

$\triangle$ Correspondence should be addressed: Marina V. Olkova

Gubkina 3, Moscow, 119991; genetics@inbox.ru

Received: 26.11.2020 Accepted: 12.12.2020 Published online: 12.01.2021

DOI: 10.24075/brsmu.2021.001

\section{АНАЛИЗ ЧАСТОТ 13 ПОЛИМОРФИЗМОВ В ГЕНАХ ТР5З И WRАР5З В РОССИЙСКИХ ПОПУЛЯЦИЯХ}

\author{
М. В. Олькова ${ }^{1,2} \bowtie$, В. С. Петрушенко², Г. Ю. Пономарев ${ }^{2}$
}

${ }^{1}$ Медико-генетический научный центр имени академика Н. П. Бочкова, Москва, Россия

2 Институт общей генетики имени Н. И. Вавилова РАН, Москва, Россия

В последнее десятилетие поиск и аннотация ассоциированных с фенотипом геномных полиморфизмов человека, а также изучение их популяционных частот стали особенно актуальными в связи с возможностью их применения в медицинской и популяционной генетике, фармакогеномике и эволюционной биологии. Целью исследования было рассчитать частоту и проанализировать распространенность в 28 российских популяциях 13 герминальных полиморфизмов двух генов - TP53, матрицы «хранителя генома» белка р53 и гена WRAP53, влияющего на производство белка р53. Были получены данные для 9 экзонных вариантов гена TP53 (rs587781663, rs17882252, rs150293825, rs112431538, rs149633775, rs144340710, rs1042522, rs1800371, rs201753350), одного интронного полиморфизма (rs17881850), а также трех вариантов гена WRAP53 (rs17880282, rs2287499, rs34067256). Для большинства популяций выборка была представлена числом более 50 человек (за исключением пяти популяций, в которых было обследовано от 30 до 49 человек). Популяционные частоты альтернативных аллелей изученных генных вариантов в большинстве российских популяций оказались близки к значениям частот этих аллелей в соответствующей их происхождению европейской или азиатской популяции из мировых баз данных. Исключение составили шесть популяций («Центральный Кавказ», «Дагестан», «северные русские», «юго-восточные русские», «татары» и «Закавказье»), в которых популяционные частоты альтернативных аллелей для большинства маркеров оказались повышенными. Для всех вышеперечисленных популяций, кроме «юго-восточных русских», характерно несоответствие аллелей полиморфизмов с повышенными частотами равновесию Харди-Вайнберга.

Ключевые слова: p53, TP53, WRAP53, онкомаркер, полиморфизм, популяционная частота, генетическая эпидемиология

Благодарности: О. П. Балановскому, заведующему лабораторией геномной географии Института общей генетики им. Н. И. Вавилова, за руководство исследованием и правку статьи, всем донорам ДНК и АНО «Биобанк Северной Евразии» за предоставленную коллекцию образцов, а также Центру высокоточного редактирования и генетических технологий для биомедицины РНИМУ им. Н. И. Пирогова (Москва, Россия) за возможность использования молекулярно-генетических технологий.

Финансирование: исследование выполнено в рамках Государственного задания Министерства науки и высшего образования РФ для Медикогенетического научного центра им. академика Н. П. Бочкова (работы по фенотипированию образцов, созданию базы данных, анализу данных).

Вклад авторов: М. В. Олькова - дизайн, статистический анализ, написание текста статьи; В. С. Петрушенко - биоинформатический анализ, Г. Ю. Пономарев - экспериментальные работы.

Соблюдение этических стандартов: исследование проведено в соответствии с требованиями Хельсинкской декларации Всемирной медицинской ассоциации. Все образцы для исследования получены из «Биобанка Северной Евразии». От всех доноров получено добровольное информированное согласие.

$\bowtie$ Для корреспонденции: Марина Викторовна Олькова ул. Губкина, д. З, г. Москва, 119991; genetics@inbox.ru

Статья получена: 26.11.2020 Статья принята к печати: 12.12.2020 Опубликована онлайн: 12.01.2021

DOI: 10.24075/vrgmu.2021.001 
TP53 gene is responsible for synthesis of one of the most notorious tumor suppressors, the p53 protein, which plays a vital part in maintaining genetic stability of the cell and cancer prevention. After activation due to cell damage, p53 triggers a number of cellular responses aimed at cell recovery and survival, or, in case the recovery is impossible, at programmed cell death. Such diverse pleiotropic tissue effects of p53 are due to total effect of co-expressed p53 isoforms. To date, at least 12 p53 isoforms have been reported, which are produced through alternative initiation of translation, the alternative promoter usage and alternative splicing [1]. All p53 isoforms share the common DNA-binding domain, but contain distinct transactivation and inhibitory domain, enabling the differential regulation of gene expression [2].

The TP53 gene shows an autosomal dominant pattern of inheritance; it is associated with the risk of Li-Fraumeni syndrome and other hereditary cancer syndromes. The altered sensitivity to certain medications in people with a number of TP53 gene polymorphisms has been confirmed (Table 1).

The region of WRAP53 gene with at least three alternative promoters is located in the region 13.1 of the short arm of chromosome 17 partially overlapping the 5'-region of the TP53 gene, which is located on the chain oppositely oriented to WRAP53 in a head-to-head orientation [3]. The WRAP53 gene plays a dual role. First, it encodes the antisense RNA (WRAP53 $\alpha$ ), which regulates the levels of p53 mRNA through interaction with the first exon of TP53, and is also involved in stimulation of p53 protein production due to its impact on the 5'- untranslated region of p53 mRNA [4, 5]. Second, WRAP53 is responsible for WRAP53 $\beta$ protein (also called WDR79 and TCAB1) synthesis; WRAP53 3 belongs to WD40 protein family. This protein contributes to maintaining the integrity and normal function of the Cajal bodies essential for maturation of the splicing machinery and telomere maintenance [6-8]. WRAP53 $\beta$ also promotes accumulation of the repair factor 53BP1 at DNA double-strand breaks, thus stimulating the DNA repair [9]. The WRAP53 $\beta$ protein possibly possesses oncogenic properties, as evidenced by the WRAP53 $\beta$ overexpression in various cancer cell lines compared to normal cells $[7,8]$. It should be noted that the involvement of this protein in carcinogenesis currently remains questionable: there is a theory that overexpression may be caused by the involvement of WRAP53 $\beta$ in DNA multiple double-strand break repair in case of cancer development in certain tissue [7].

The WRAP53 gene mutations show the autosomal recessive pattern of inheritance. The homozygous mutations of this gene may result in dyskeratosis congenita and Li-Fraumeni syndrome.

The clinical significance of genes TP53 and WRAP53, as well as high prevalence of their germline pathogenic variants in various cancer types [10], explain the need for studying the frequencies of these genes in populations of different countries. The frequencies of polymorphisms of these genes have already been studied in some European countries and the United States: the details on frequencies of both clinically significant polimorphisms and markers with uncertain significance may be found on the web-sites of such projects as ClinVar [11] of the National Center for Biotechnology Information of the USA, Ensembl (joint scientific project of the European Bioinformatics Institute and Sanger Institute) [12], and Genome Aggregation Database (gnomAD) [13]. In Russia, "Genokarta", the website of genetic encyclopedia created by researchers from the Novosibirsk State University is being actively developed [14]. Our study aimed at exploring distribution and frequencies of 13 polymorphisms of TP53 and WRAP53 genes in Russian populations is directed to expand the scientific knowledge in this area with regard to populations living in our country.

\section{METHODS}

\section{DNA sampling}

DNA samples were provided by Biobank of North Eurasia [15]. DNA was extracted from blood and saliva using the standard phenol-chloroform extraction method. The study included 1,785 DNA samples of volunteers who belonged to 28 Russian populations, which, based on their places of residence, covered the main regions of Russia (Table 2). Inclusion criteria: volunteers belonging to certain ethnic group (based on the self-identified ethnicity in four or more generations). Exclusion criteria: samples failing to meet criteria of belonging to certain ethnic group. Since the study was aimed at investigation of autosomal markers, the gender distribution was not taken into account during DNA sampling.

The size of each population was $30-87$ people. The composition of studied populations is presented in Table 2. It should be taken into account that the studied genes TP53 and WRAP53 were autosomal, therefore, the actual number of studied alleles was twice as much: 60-174 alleles for each population.

\section{Selection of polymorphisms}

The list of TP53 and WRAP53 polymorphisms was established based on genetic variants with proven clinical significance submitted to ClinVar database (except the TP53 intronic variant, rs17881850). The intronic variant rs17881850 was included in the study in order to compare the allele frequencies of neutral polymorphism with the allele frequencies of genetic variants with confirmed clinical significance. Unfortunately, after genotyping much of polymorphisms included in original list had to be excluded from analysis, i. e. the population frequencies were calculated only using markers genotyped successfully in all populations.

\section{Genotyping}

All individuals were genotyped for nine TP53 exon polymorphisms (rs587781663, rs17882252, rs150293825, rs112431538, rs149633775, rs144340710, rs1042522, rs1800371, rs201753350) and one intronic variant (rs17881850), as well as for three WRAP53 polymorphisms (rs17880282, rs2287499, rs34067256). Genotyping was carried out using the Illumina (Illumina Inc.; USA) genomic analysis microarray technology. The standard 0.15 GenCall score cutoff value was used to discard the poorly typed samples.

\section{Basic data on studied polymorphisms}

Full information on studied polymorphisms was obtained from the web-site of the National Center for Biotechnology Information of the USA [16], in particular from the ClinVar archive [17] and Genome Aggregation Database (gnomAD) [18]. The position of polymorphism in the human genome was specified based on the version GRCh38.p12 of human reference Genome Assembly (Table 1).

Since the information about some polymorphisms available from public domains was incomplete, all markers were also studied by functional analysis through hidden Markov models designed for prediction of missense protein variants using the 


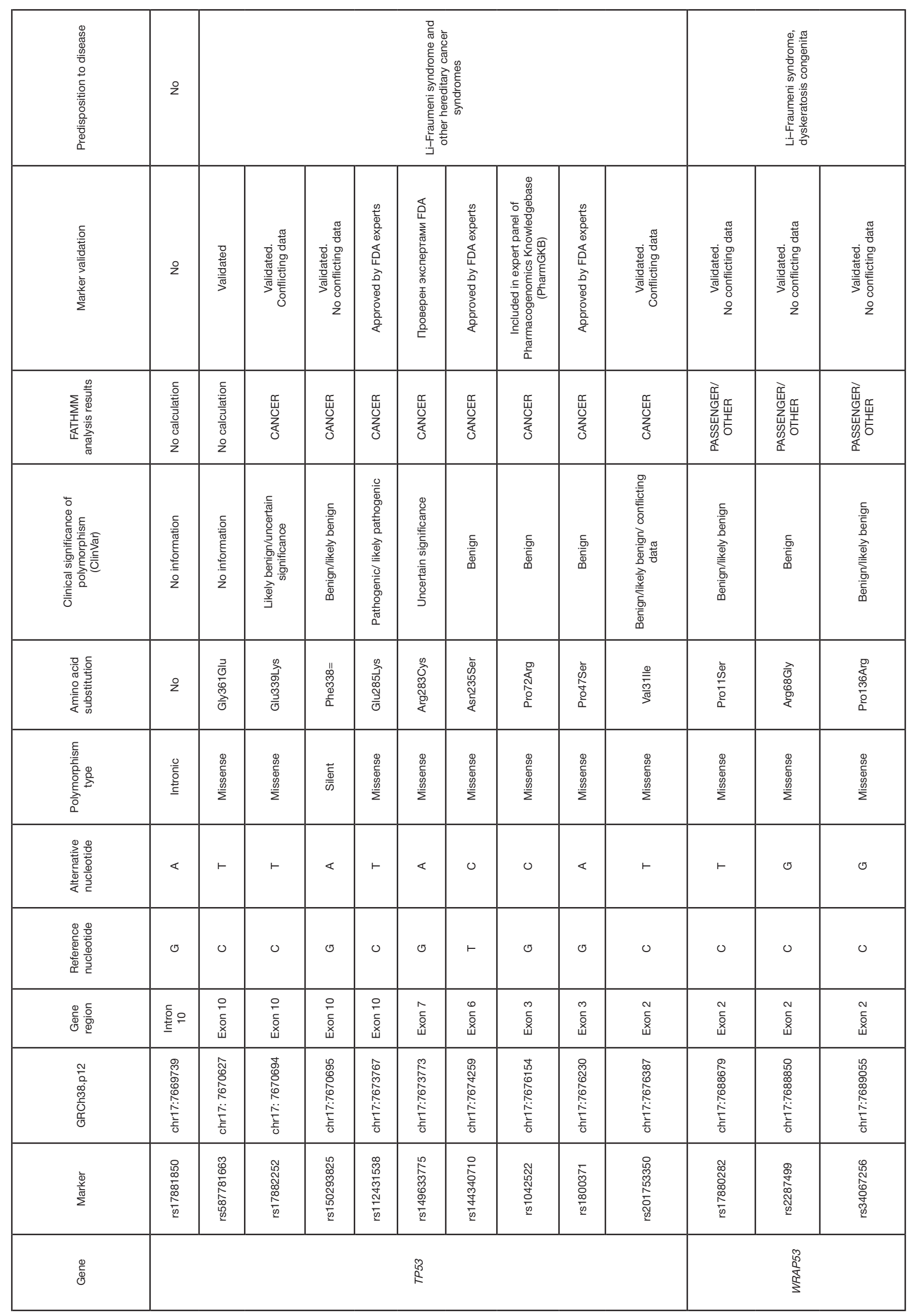




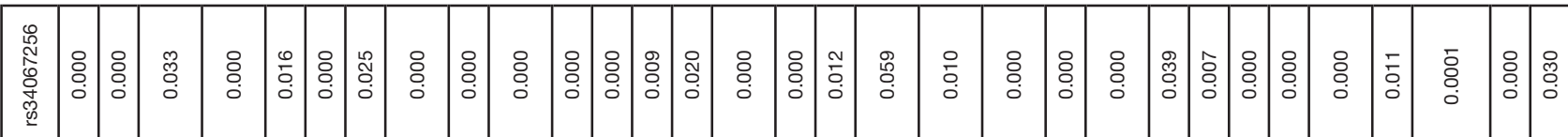

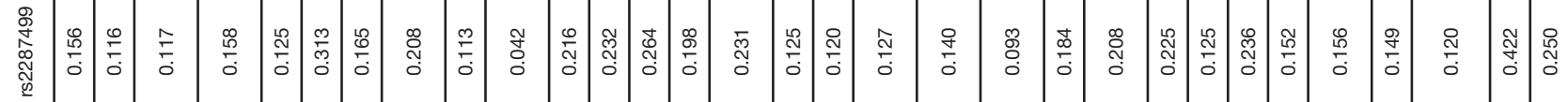

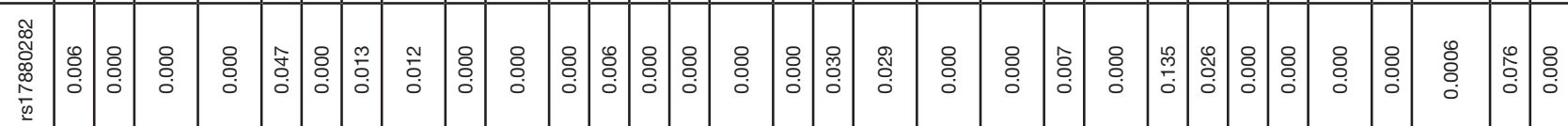

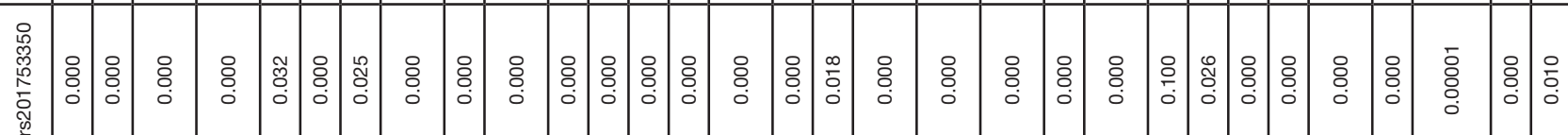

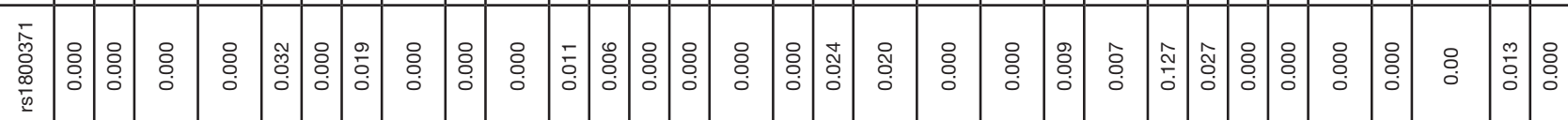

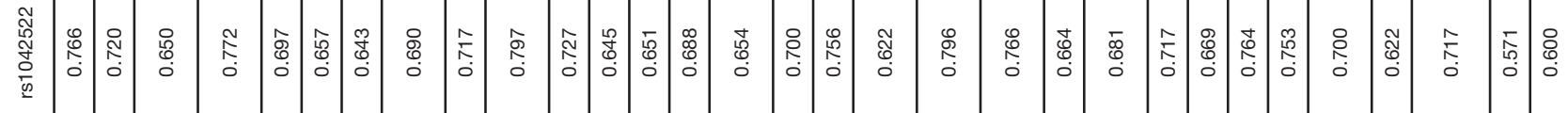

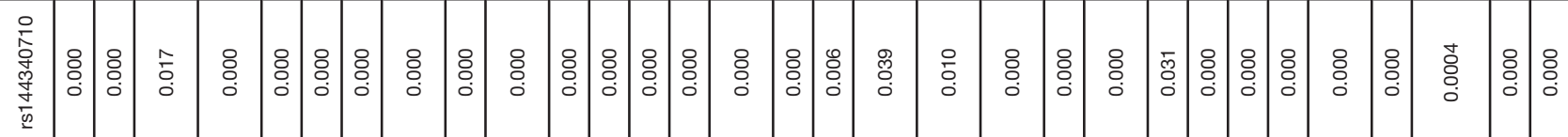

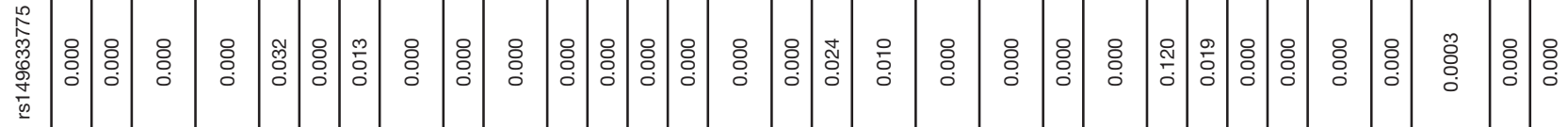

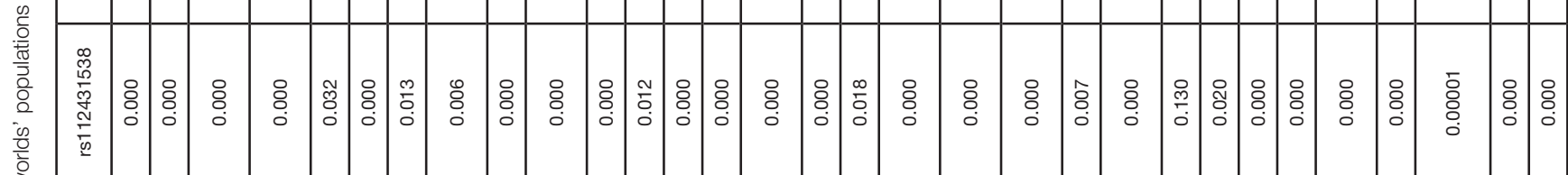

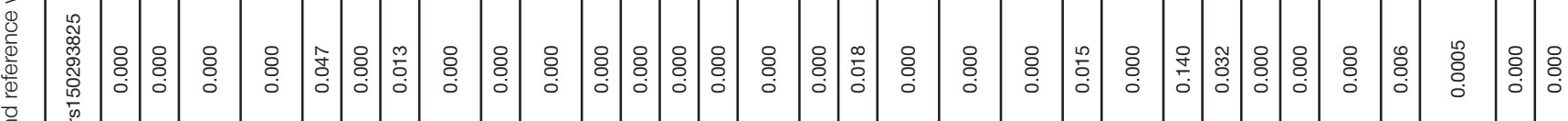

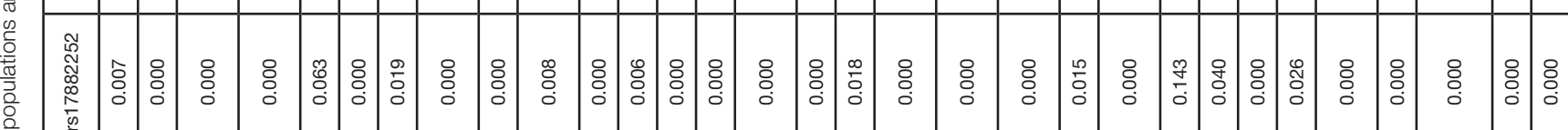

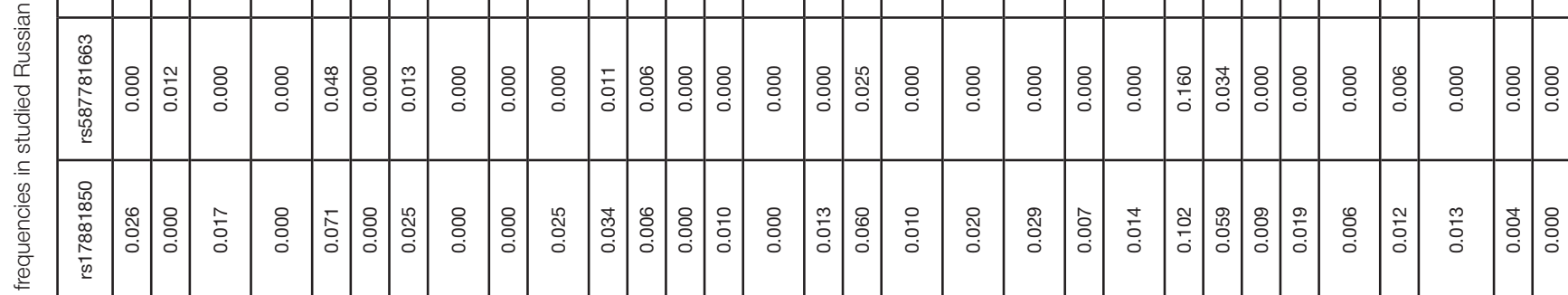

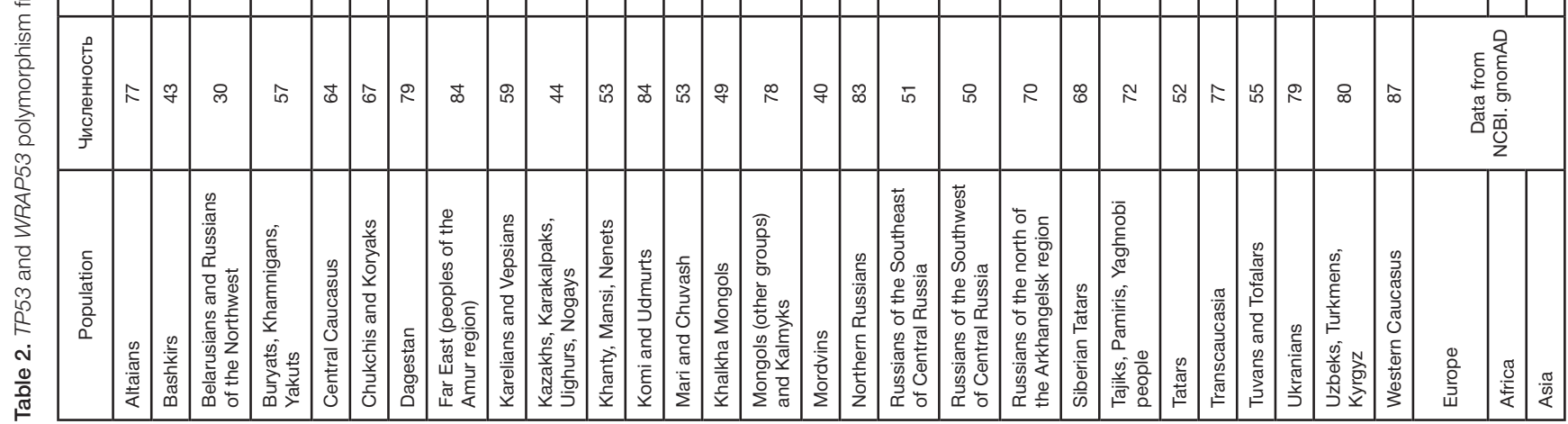


fathmm web-site [19]. To minimize the number of false positives, a conservative threshold of -3.0 was chosen for analysis. The data obtained were included in Table. 1.

\section{Mathematical and statistical methods}

Calculation of population alternative allele frequencies for studied polymorphisms, calculation of $\chi^{2}$ criterion and $p$-value for assessment of Hardy-Weinberg genotype frequencies, as well as assessment of alternative allele frequency distribution normality in studied populations were performed with RStudio R, version 4.0.2 (RStudio; USA) and Microsoft Excel (Microsoft Corp.; USA). The differences were considered significant at $p<0.01$

\section{Multidimensional scaling}

Two-dimensional representation of spatial distribution of populations based on the alternative allele frequencies calculated for studied markers TP53 and WRAP53 was obtained with STATISTICA10 software package (StatSoft; USA) via multidimensional scaling using the Nei's genetic distances calculated with the DJ genetic software (RCMG; Russia).

\section{RESULTS}

\section{Calculation of alternative allele frequencies for studied markers in Russian populations}

Based on the genotyping of 28 Russian populations, we calculated alternative allele frequencies for nine exon TP53 polymorphisms (exon 2 - rs201753350; exon 3 - rs1042522, rs1800371; exon 6 - rs144340710; exon 7 - rs112431538, rs149633775; exon 10 - rs587781663, rs17882252, rs150293825), one intronic TP53 variant (rs17881850), as well as for three polymorphisms of exon 2 of WRAP53 gene (rs17880282, rs2287499, rs34067256). The calculated population alternative allele frequencies for the listed markers are presented in Table 2.

\section{Alternative allele frequencies and Hardy-Weinberg equilibrium}

To test the studied markers TP53 and WRAP53 for HardyWeinberg equilibrium in the population, $\chi^{2}$ criterion was calculated based on the existing allele ratio and the calculated in accordance with the Hardy-Weinberg principle marker population frequencies. Table 3 was compiled in order to visualize the relationship between the alternative allele frequencies and the Hardy-Weinberg equilibrium. In five of 28 studied populations ("Central Caucasus", "Dagestan", "northern Russians", "Tatars" and "Transcaucasia") the combination of high (compared to the listed in Table 2 reference frequencies for the world's populations of appropriate origin) alternative allele frequencies and their non-equilibrium pattern in the population (orange cells) were observed for most markers. This suggests that the external factors (for example, accidental inbreeding) may affect the pattern of studied alleles in the discussed population. Genotyping errors may also affect the results.

In the population of "southeastern Russians" alternative alleles for many markers were identified; the frequencies of those were higher compared to reference European population, however, the alleles showed no deviation from the HardyWeinberg equilibrium.
In some populations ("Komi and Udmurts", "Siberian Tatars", "Western Caucasus"), the diversity of identified markers was higher compared to reference populations of appropriate origin, however, their frequencies were low (close to reference values) and satisfied the Hardy-Weinberg principle. Among studied markers, two markers (rs1042522, located in exon 3 of TP53, and rs2287499, located in exon 2 of WRAP53) were characterized by high frequencies and satisfied the HardyWeinberg principle in all populations.

\section{Assessment of normality for distribution of alternative allele frequencies in the populations}

Since in theory the neutral alleles are not affected by natural selection, and their population frequencies may follow a normal distribution, we have assessed the normality of the marker frequency distribution in the population using the Shapiro-Wilk test. The test results have made it possible to confirm the nullhypothesis for two markers: rs1042522 ( $\mathrm{W}=0.95, p=0.18$ ) and rs2287499 ( $\mathrm{W}=0.97, p=0.46)$. For other markers, the normal distribution has not been confirmed.

\section{Analysis of marker population frequencies by multidimensional scaling (MDS)}

In our study, multidimensional scaling was the most effective method for the studied populations' positioning in the lowdimensional space allowing us to evaluate the genetic distances between populations. MDS was performed for 29 populations (Tatar and African populations were excluded due to sharp contrast between their marker frequencies and the data for the main population pool) (see Figure). For the MDS performed the stress value was 0.068 , and the alienation coefficient was 0.058 .

The populations were pre-labeled as belonging to one of three groups: Asian, European and Caucasian. The populations grouped based on their origin (see Figure) allowed us to determine three appropriate clusters: Asian, European and Caucasian. In the Asian and European clusters having the overlap area of a significant size, the populations are closer to each other based on polymorphism frequencies, and in the Caucasian cluster, the large frequencies' variability between populations is observed.

The boundaries of Asian cluster are quite clear. The only exception is the joint population which includes Kazakhs, Karakalpaks, Uighurs and Nogais; the position of this population outside the cluster is due to higher level of some markers showing the equilibrium pattern compared to other Asian populations (Table 3).

European cluster has a more compact shape with high population density around the central reference European population, the marker frequencies for which have been obtained from public sources. The following three European populations appear to be far beyond the cluster: "northern Russians", "southeastern Russians" and the joint population of Mari and Chuvash. The population of "northern Russians" is the only European population showing higher frequencies of many markers deviating from equilibrium, which are absent in other European population (Table 3). Compared to the "northern Russians" population, the population of "southeastern Russians" characterized by high frequencies of some polymorphisms unusual for European populations, the majority of which are in Hardy-Weinberg equilibrium (Table 3), is extended beyond European cluster in the opposite direction on the plot. The "Mari and Chuvash" population is deep inside the Asian cluster, which may be due to anthropological composition 


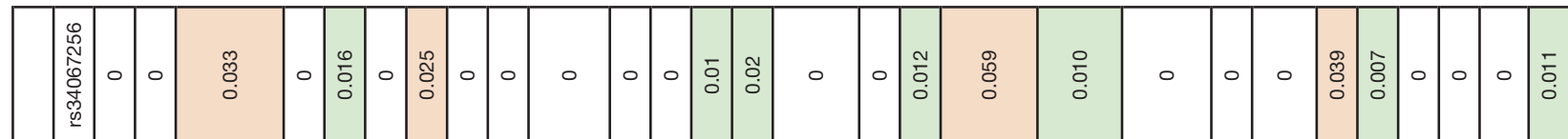

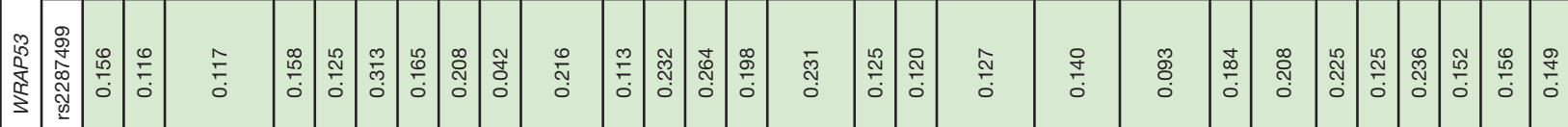

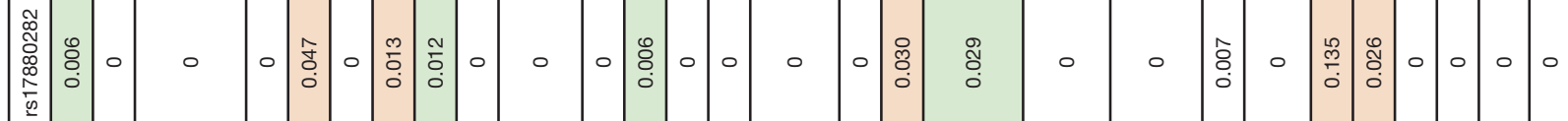

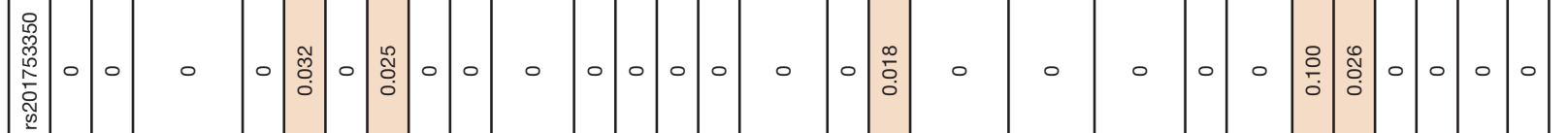

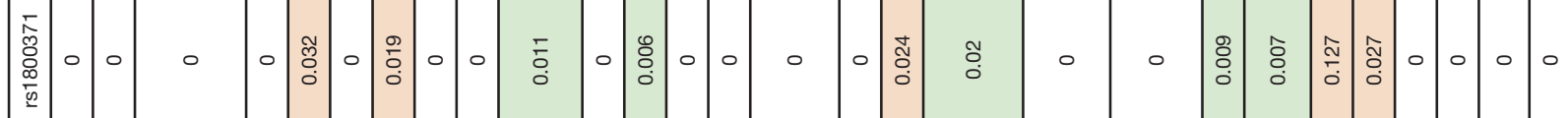

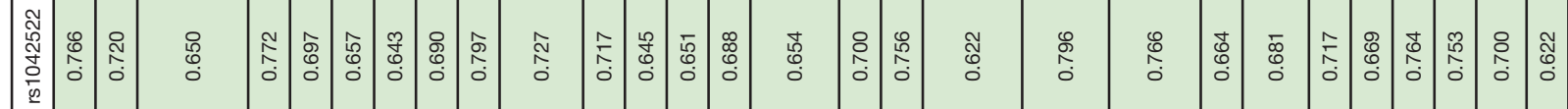
인

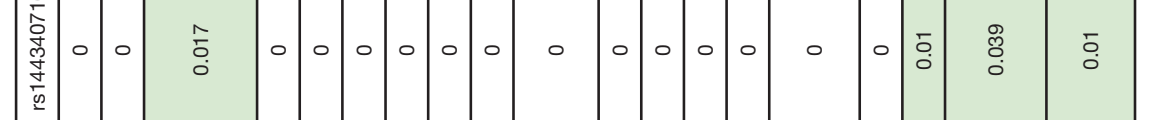
苾

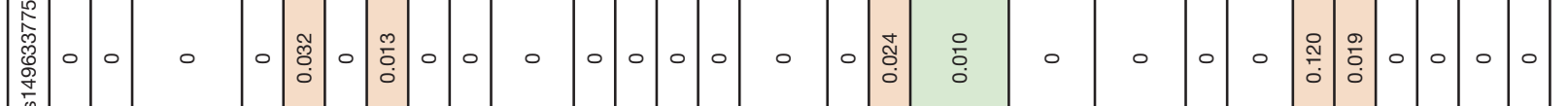

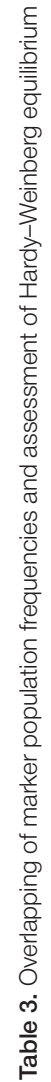

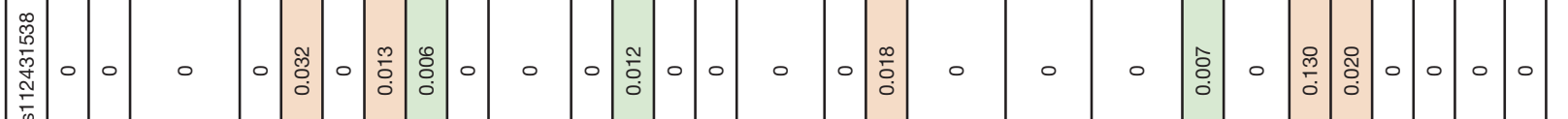

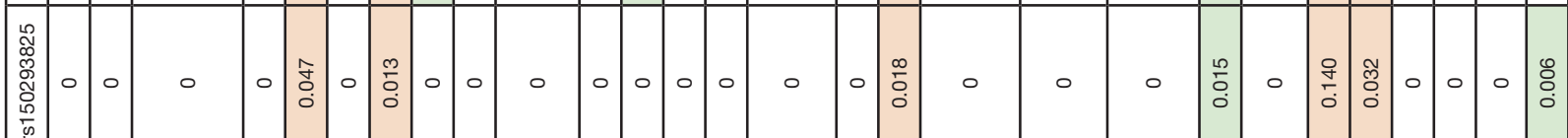

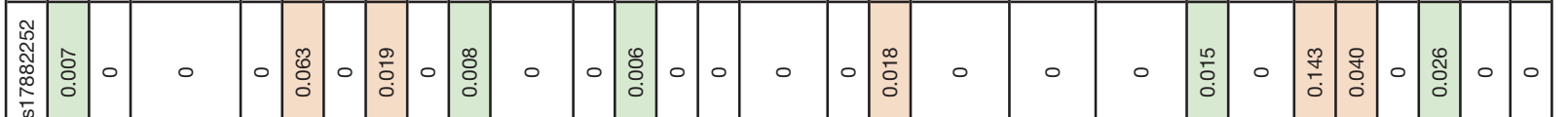

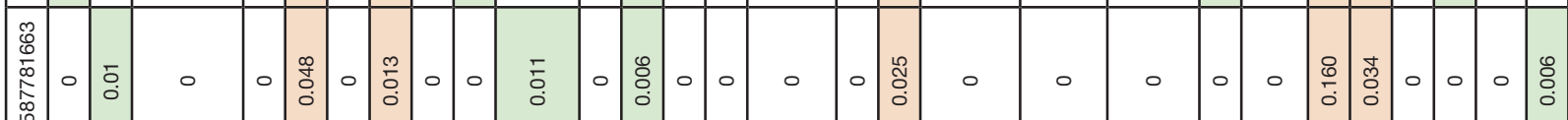

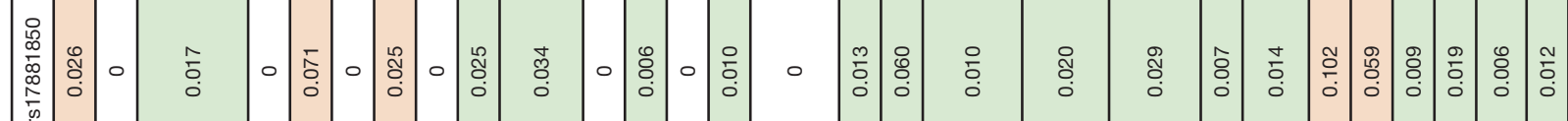

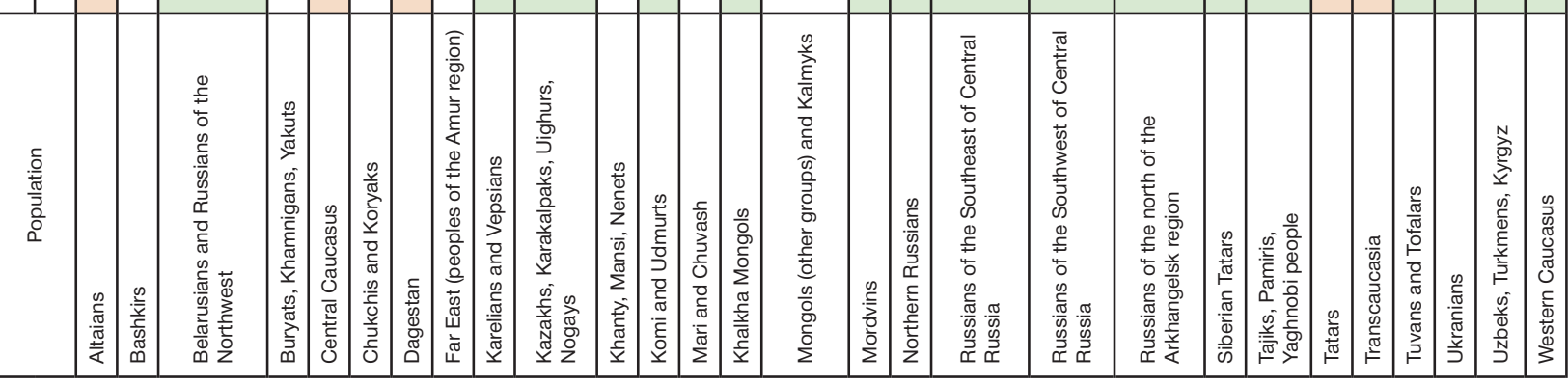




\section{ORIGINAL RESEARCH I GENETICS}

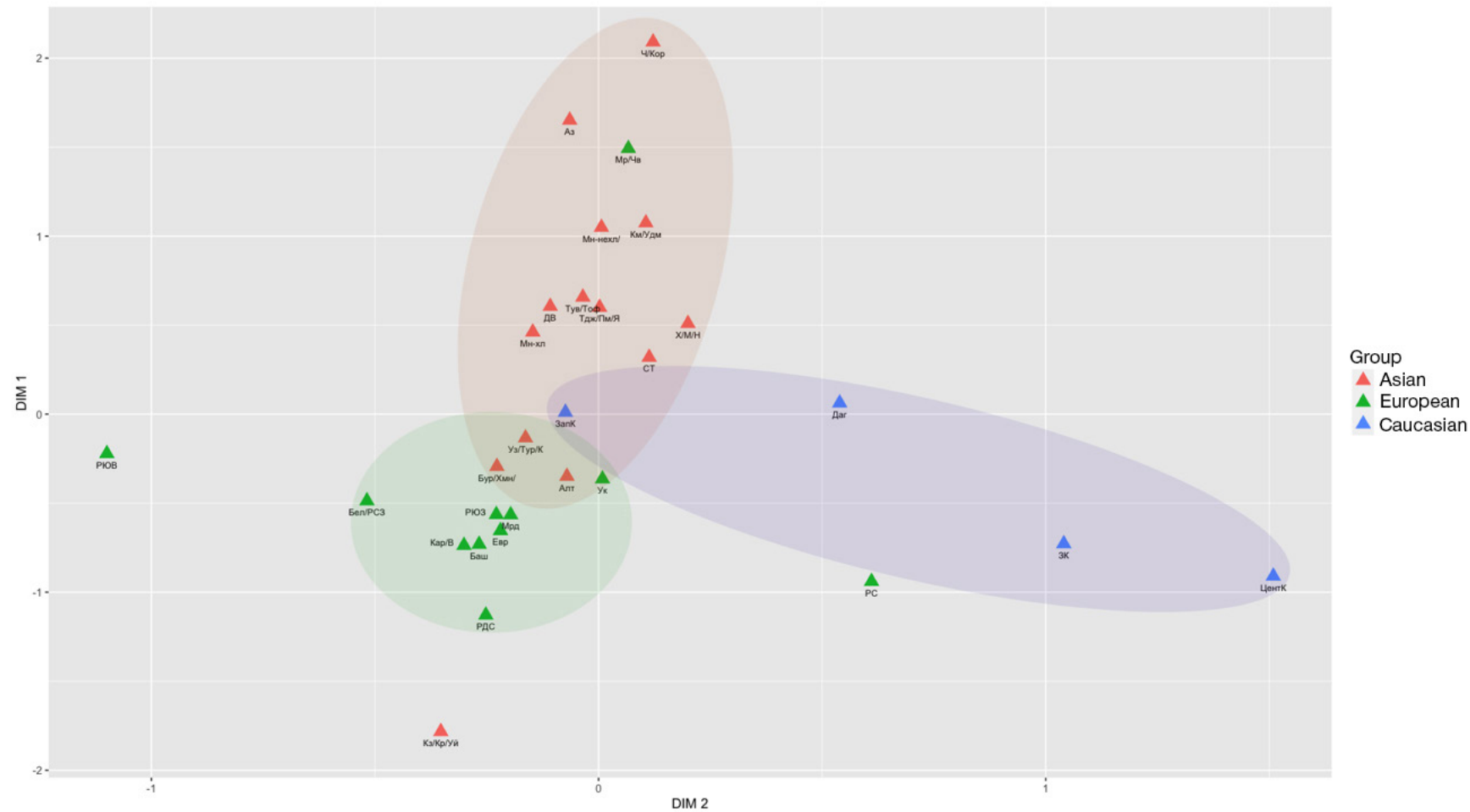

\begin{tabular}{|c|c|}
\hline Алт & Altaians \\
\hline Баш & Bashkirs \\
\hline Бел/РСЗ & Belarusians and Russians of the Northwest \\
\hline Бур/Хмн/ & Buryats, Khamnigans, Yakuts \\
\hline ЦентК & Central Caucasus \\
\hline 4/Kop & Chukchis and Koryaks \\
\hline Даг & Dagestan \\
\hline ДВ & Far East (peoples of the Amur region) \\
\hline Kap/B & Karelians and Vepsians \\
\hline Кз/Кр/Уй & Kazakhs, Karakalpaks, Uighurs, Nogays \\
\hline $\mathrm{X} / \mathrm{M} / \mathrm{H}$ & Khanty, Mansi, Nenets \\
\hline Км/Удм & Komi and Udmurts \\
\hline Мр/Чв & Mari and Chuvash \\
\hline Мн-хл & Khalkha Mongols \\
\hline Мн-нехл/ & Mongols (other groups) and Kalmyks \\
\hline Мрд & Mordvins \\
\hline PC & Northern Russians \\
\hline PЮB & Russians of the Southeast of Central Russia \\
\hline РЮ3 & Russians of the Southwest of Central Russia \\
\hline РДС & Russians of the north of the Arkhangelsk region \\
\hline CT & Siberian Tatars \\
\hline Тдж/Пм/я & Tajiks, Pamiris, Yaghnobi people \\
\hline 3K & Transcaucasia \\
\hline Тув/Тоф & Tuvans and Tofalars \\
\hline $\mathrm{y}_{\mathrm{K}}$ & Ukranians \\
\hline $\mathrm{Y}_{3} / \mathrm{Typ} / \mathrm{K}$ & Uzbeks, Turkmens, Kyrgyz \\
\hline ЗапК & Western Caucasus \\
\hline Евр & Europe \\
\hline Аз & Asia \\
\hline
\end{tabular}

Fig. Multidimensional scaling plot based on Nei's genetic distance matrix for 29 populations (Tatar and African populations were excluded from analysis due to excessively large frequency differences with the rest of populations); stress value is 0.068 , and the alienation coefficient is 0.058 . The populations are divided into three groups: Asian (red triangle), European (green triangle) and Caucasian (b/ue sign). The appropriate clusters have been distinguished: orange — Asian populations, green — European populations, blue - Caucasian populations. 
of the Chuvash that includes both Caucasian individuals and a significant proportion of Mongoloid individuals together with mixed forms.

All populations of Caucasian cluster, except for the "Western Caucasus" population falling in the overlap area with Asian cluster and being in the close proximity to European cluster, are characterized by high frequencies of all analyzed polymorphisms and their non-equilibrium patterns (Table 3), which brings them close to "northern Russians" based on the discussed parameters (see Figure).

\section{DISCUSSION}

The study of TP53 and WRAP53 gene polymorphisms in 28 populations covering all major regions of Russia made it possible to assess the frequency and distribution of selected markers in various Russian regions and populations.

Assessment of alternative allele frequencies for the studied markers in Russian populations revealed two major trends:

- two of 13 studied markers (rs1042522, located in exon 3 of TP53, and rs2287499, located in exon 2 of WRAP53) are characterized by high frequencies in all populations, normal distribution of marker population frequencies, and HardyWeinberg proportions of alleles;

- in five populations ("Central Caucasus", "Dagestan", "northern Russians", "Tatars" and "Transcaucasia"), the frequencies of most markers (except the mentioned above rs1042522 and rs2287499, as well as the benign rs144340710 located in exon 6 of TP53) appeared to be high, and the alleles of these markers showed non-equilibrium patterns. In the Tatar population the abundance, frequencies and distribution of the studied polymorphisms' alternative alleles were significantly higher compared to reference global values; they also significantly exceeded the frequencies and abundance of these polymorphisms in the major pool of Russian populations (Table 2). This matter is subject to further research.

Two prevalent equilibrium markers, rs1042522 of TP53 gene and rs2287499 of WRAP53 gene, are listed in the ClinVar data base as benign markers. It means that their frequency is too high for markers to be pathogenic mutations; markers are found in hetero- and homozygous state in individuals without severe disease for that gene; markers show no disease association in appropriately sized case-control studies [20]. The fact that the alternative allele of rs1042522 polymorphism being a part of p53 DNA-binding domain [21] shows high frequency in all populations compared to reference genome may indicate the reference genome carrying a random minor allele. This assumption is indirectly supported by the reported increased functional ability to induce apoptosis and prevent cancer development in alternative Arg72 variant of p53 protein compared to reference Pro72 variant [22].

Despite rs1042522 and rs2287499 are listed in scientific databases as benign markers, literature contains a large amount of data on their involvement in carcinogenesis. In particular, it has been reported that heterozygous variant Arg/ Pro of p53 Pro72Arg polymorphism (Table 1) is associated with high risk of melanoma compared to heterozygous variant Pro/Pro
[23]; another paper reports association of the marker Pro/Pro genotype with increased risk of nonsmall cell lung cancer in patients from Moscow Region [21].

There are many literary sources on survival of cancer patients, homo- and heterozygous for Pro72Arg, however, the reported data is controversial. There is evidence of increased median survival time in cervical cancer patients carrying Arg/Pro genotype when compared with patients with Arg/Arg and Pro/ Pro genotypes [24], however, the extensive research carried out by Danish specialists [25] has shown no association of the mentioned above polymorphism with lower mortality after cancer and lower cancer incidence in the general population.

However, rs1042522 is better known as a marker included in the expert panel of Pharmacogenomics Knowledgebase, which is associated with altered body response to some antineoplastic drugs [26]. There is evidence of the p53 Pro allele association with toxicity due to chemotherapy [27], as well as evidence of lower response rate to fluorouracil-based chemotherapy in gastric cancer patients carrying the Pro/Pro genotype compared to patients carrying the Arg/Arg genotype [28].

The clinical significance of rs2287499 marker of gene WRAP53 is much less well understood, however, there is evidence of moderate linkage disequilibrium between studied markers rs1042522 and rs2287499. The haplotype combination CA/GC is associated with increased risk of breast cancer, and the haplotype combination GA/CC, by contrast, is assumed to be a protective factor against breast cancer [29].

The abundance and frequencies of other polymorphisms in Russian populations vary significantly, however the calculated frequencies of most polymorphisms correspond to reference marker frequencies for Asian and European populations in accordance with the origin of surveyed Russian populations. Exceptions are five listed above populations with high frequencies of the discussed markers. The clinical significance of some studied polymorphisms (for example, the intronic variant rs17881850) remains poorly understood. However, recent evidence suggests that intronic TP53 gene polymorphisms may also have some clinical significance [30].

\section{CONCLUSION}

The study allowed us to obtain data on germline TP53 (10 markers of five exons and one intron) and WRAP53 (three markers of exon 2) polymorphism frequencies for 28 Russian populations. In the majority of populations the calculated polymorphism frequencies are close to values obtained for reference global population (Asian or European) of appropriate origin. Six populations ("Central Caucasus", "Dagestan", "northern Russians", "south-eastern Russians", "Tatars" and "Transcaucasia") are characterized by increased marker frequencies compared to reference values; in all listed populations except the population of "southeastern Russians" the marker alleles with high frequencies do not satisfy the Hardy-Weinberg principle. The Tatar population is characterized by high frequencies of polymorphisms' allelic disequilibrium, which demonstrates the need for more detailed investigation of those in this population in order to reveal the cause of such differences. 
1. Joruiz SM, Bourdon JC. P53 isoforms: Key regulators of the cell fate decision. Cold Spring Harbor Perspectives in Medicine. 2016; 6: 8.

2. Surget S, Khoury MP, Bourdon JC. Uncovering the role of p53 splice variants in human malignancy: a clinical perspective. OncoTargets and Therapy. 2013; 7: 57-68.

3. Rassoolzadeh $\mathrm{H}$. Unwrapping the role of WRAP53 $\beta$ in DNA damage response [Internet]. [Solna]; 2016. Available from: http:// ceder.graphics.

4. Mahmoudi S, Henriksson S, Corcoran M, Méndez-Vidal C, Wiman KG, Farnebo M. Wrap53, a natural p53 antisense transcript required for p53 induction upon DNA damage. Molecular Cell. 2009; 33 (4): 462-71

5. Farnebo M. Wrap53, a novel regulator of p53. Cell Cycle. 2009; 8 (15): 2343-6. DOI: 10.4161/cc.8.15.9223.

6. Henriksson S, Farnebo M. On the road with WRAP53 $\beta$ : guardian of Cajal bodies and genome integrity. Front Genet. 2015; 6: 91. doi: 10.3389/fgene.2015.00091.

7. Bergstrand S, O'Brien EM, Farnebo M. The Cajal body protein WRAP53 $\beta$ prepares the scene for repair of DNA double-strand breaks by regulating local ubiquitination. Front Mol Biosci. 2019; 6: 51. Published 2019 Jul 4. DOI:10.3389/fmolb.2019.00051

8. Mahmoudi S. WRAP53 unwrapped; roles in nuclear architecture and cancer. 2011.

9. Coucoravas C, Dhanjal S, Henriksson S, Böhm S, Farnebo M. Phosphorylation of the Cajal body protein WRAP53 $\beta$ by ATM promotes its involvement in the DNA damage response. RNA Biol. 2017; 14(6): 804-13. DOl:10.1080/15476286.2016.1243647.

10. Rogoża-Janiszewska E, Malińska K, Górski B, Scott RJ, Cybulski C, Kluźniak W, et al. Prevalence of germline TP53 variants among early-onset breast cancer patients from Polish population. Breast Cancer. 2020.

11. rs2287499 RefSNP Report - dbSNP - NCBI [Internet]. Available from: https://www.ncbi.nlm.nih.gov/snp/rs2287499\#frequency_tab.

12. rs2287499 (SNP) - Population genetics — Homo_sapiens Ensembl genome browser 101 [Internet]. Available from: http://www.ensembl.org/Homo_sapiens/Variation/ Population?db=core; $r=17: 7688350-7689350 ; \mathrm{v}=\mathrm{rs} 2287499 ; \mathrm{vdb}=\mathrm{V}$ ariation; $\mathrm{vf}=87573072$

13. rs2287499|gnomAD v2.1.1 |gnomAD [Internet]. Available from: https:// gnomad.broadinstitute.org/variant/rs2287499?dataset=gnomad_r2_1.

14. rs2287499 C>G | Genokarta — geneticheskaja enciklopedija [Internet]. Available from: https://genokarta.ru/snps/rs2287499_CG.

15. Balanovskaya EV, Zhabagin MK, Agdzhoyan AT, Chukhryaeva MI, Markina NV, Balaganskaya OA et al. Populyaczionnye biobanki: princzipy organizaczii i perspektivy primeneniya $\vee$ genogeografii i personalizirovannoj mediczine. Genetika. 2016; 52 (12): 1371-87.

16. National Center for Biotechnology Information [Internet]. Available from: https://www.ncbi.nlm.nih.gov/.

17. What is ClinVar? [Internet]. Available from: https://www.ncbi.nlm.

\section{Литература}

1. Joruiz SM, Bourdon JC. P53 isoforms: Key regulators of the cell fate decision. Cold Spring Harbor Perspectives in Medicine. 2016; 6: 8 .

2. Surget S, Khoury MP, Bourdon JC. Uncovering the role of p53 splice variants in human malignancy: a clinical perspective. OncoTargets and Therapy. 2013; 7: 57-68.

3. Rassoolzadeh $\mathrm{H}$. Unwrapping the role of WRAP53 $\beta$ in DNA damage response [Internet]. [Solna]; 2016. Available from: http:// ceder.graphics.

4. Mahmoudi S, Henriksson S, Corcoran M, Méndez-Vidal C, Wiman KG, Farnebo M. Wrap53, a natural p53 antisense transcript required for p53 induction upon DNA damage. Molecular Cell. 2009; 33 (4): 462-71.

5. Farnebo M. Wrap53, a novel regulator of p53. Cell Cycle. 2009; 8 (15): 2343-6. DOI: 10.4161/cc.8.15.9223.

6. Henriksson S, Farnebo M. On the road with WRAP53ß: guardian nih.gov/clinvar/intro/.

18. gnomAD [Internet]. Available from: https://gnomad.broadinstitute. org/.

19. fathmm - Home [Internet]. Available from: http://fathmm. biocompute.org.uk/.

20. Pesaran T, Karam R, Huether R, Li S, Farber-Katz S, Chamberlin A, et al. Beyond DNA: an integrated and functional approach for classifying germline variants in breast cancer genes. Int J Breast Cancer. 2016; 2016: 2469523. DOI: 10.1155/2016/2469523.

21. Zavarykina T, Byrdennyy A, Loginov V, Atkarskaya M, Zhizhina G. A84: Polymorphic markers Arg72Pro and Gln157Lys of TP53 gene in nonsmall cell lung cancer. European Journal of Cancer Supplements [Internet]. 2015; 13 (1): 69. Available from: https:// linkinghub.elsevier.com/retrieve/pii/S1359634915001238.

22. Zheltuhin $A O$, Chumakov PM. Povsednevnye i induciruemye funkcii gena p53. 2010; 50: 447-516.

23. Geng $P$, Liao $Y$, Ruan Z, Liang $H$. Increased risk of cutaneous melanoma associated with p53 Arg72pro polymorphism. PLoS ONE [Internet]. 2015; 10 (3): e0118112. Available from: https:// dx.plos.org/10.1371/journal.pone.0118112.

24. Coelho A, Nogueira A, Soares S, Assis J, Pereira D, Bravo I, et al. TP53 Arg72Pro polymorphism is associated with increased overall survival but not response to therapy in Portuguese/ Caucasian patients with advanced cervical cancer. Oncology Letters [Internet]. 2018; 15 (5): 8165-71. Available from: http:// www.spandidos-publications.com/10.3892/ol.2018.8354/abstract.

25. Kodal JB, Vedel-Krogh S, Kobylecki CJ, Nordestgaard BG, Bojesen SE. TP53 Arg72Pro, mortality after cancer, and all-cause mortality in 105,200 individuals. Scientific Reports. 2017; 7 (1).

26. rs1042522 - Clinical Annotations [Internet]. Available from: https:// www.pharmgkb.org/variant/PA166155173/clinicalAnnotation.

27. Henríquez-HernándezLA, Murias-Rosales A, González-HernándezA, de León AC, Díaz-Chico N, Fernández-Pérez L. Distribution of TYMS, MTHFR, p53 and MDR1 gene polymorphisms in patients with breast cancer treated with neoadjuvant chemotherapy. Cancer Epidemiology. 2010; 34 (5): 634-8. DOI: 10.1016/j. canep.2010.06.013.

28. Huang ZH, Hua D, Li LH, Zhu J De. Prognostic role of p53 codon 72 polymorphism in gastric cancer patients treated with fluorouracil-based adjuvant chemotherapy. J Cancer Res Clin Oncol. 2008; 134 (10): 1129-34. DOl: 10.1007/s00432-008-0380-8.

29. Pouladi N, Abdolahi S, Farajzadeh D, Feizi MAH. Haplotype and linkage disequilibrium of TP53-WRAP53 locus in IranianAzeri women with breast cancer. Roemer K, editor. PLOS ONE [Internet]. 2019; 14 (8): e0220727. Available from: https://dx.plos. org/10.1371/journal.pone.0220727.

30. Voropaeva EN, Pospeloya TI, Voevoda MI, Mabimovv N. Changes in non-coding sequences of the tp53 gene in diffuse large b-cell lymphoma. Gematologiya i Transfusiologiya. 2018; 63 (3): 239-49.

of Cajal bodies and genome integrity. Front Genet. 2015; 6: 91. doi: 10.3389/fgene.2015.00091.

7. Bergstrand S, O'Brien EM, Farnebo M. The Cajal body protein WRAP53 3 prepares the scene for repair of DNA double-strand breaks by regulating local ubiquitination. Front Mol Biosci. 2019; 6: 51. Published 2019 Jul 4. DOl:10.3389/fmolb.2019.00051.

8. Mahmoudi S. WRAP53 unwrapped; roles in nuclear architecture and cancer. 2011

9. Coucoravas C, Dhanjal S, Henriksson S, Böhm S, Farnebo M. Phosphorylation of the Cajal body protein WRAP53 $\beta$ by ATM promotes its involvement in the DNA damage response. RNA Biol. 2017; 14(6): 804-13. DOI:10.1080/15476286.2016.1243647.

10. Rogoża-Janiszewska E, Malińska K, Górski B, Scott RJ, Cybulski C, Kluźniak W, et al. Prevalence of germline TP53 variants among early-onset breast cancer patients from Polish population. Breast Cancer. 2020. 
11. rs2287499 RefSNP Report - dbSNP - NCBI [Internet]. Available from: https://www.ncbi.nlm.nih.gov/snp/rs2287499\#frequency_tab.

12. rs2287499 (SNP) - Population genetics - Homo_sapiens Ensembl genome browser 101 [Internet]. Available from: http://www.ensembl.org/Homo_sapiens/Variation/ Population? $\mathrm{db}=$ core; $r=17: 7688350-7689350 ; \mathrm{v}=\mathrm{rs} 2287499 ; \mathrm{vdb}=\mathrm{V}$ ariation; $\mathrm{vf}=87573072$

13. rs2287499|gnomADv2.1.1 |gnomAD [Internet]. Available from: https:// gnomad.broadinstitute.org/variant/rs2287499?dataset=gnomad_ r2_1

14. rs2287499 C>G | Генокарта - генетическая энциклопедия [Internet]. Available from: https://genokarta.ru/snps/rs2287499_CG.

15. Балановская Е. В., Жабагин М. К., Агджоян А. Т., Чухряева М. И., Маркина Н. В., Балаганская О. А. и др. Популяционные биобанки: принципы организации и перспективы применения в геногеографии и персонализированной медицине. Генетика. 2016; 52 (12): 1371-87.

16. National Center for Biotechnology Information [Internet]. Available from: https://www.ncbi.nlm.nih.gov/.

17. What is ClinVar? [Internet]. Available from: https://www.ncbi.nlm nih.gov/clinvar/intro/.

18. gnomAD [Internet]. Available from: https://gnomad.broadinstitute. org/.

19. fathmm - Home [Internet]. Available from: http://fathmm. biocompute.org.uk/.

20. Pesaran T, Karam R, Huether R, Li S, Farber-Katz S, Chamberlin A et al. Beyond DNA: an integrated and functional approach for classifying germline variants in breast cancer genes. Int J Breast Cancer. 2016; 2016: 2469523. DOI: 10.1155/2016/2469523.

21. Zavarykina T, Byrdennyy A, Loginov V, Atkarskaya M, Zhizhina G. A84: Polymorphic markers Arg72Pro and Gln157Lys of TP53 gene in nonsmall cell lung cancer. European Journal of Cancer Supplements [Internet]. 2015; 13 (1): 69. Available from: https:// linkinghub.elsevier.com/retrieve/pii/S1359634915001238.

22. Желтухин А. О., Чумаков П. М. Повседневные и индуцируемые функции гена р53. 2010; 50: 447-516.

23. Geng $P$, Liao $Y$, Ruan Z, Liang $H$. Increased risk of cutaneous melanoma associated with p53 Arg72pro polymorphism. PLoS ONE [Internet]. 2015; 10 (3): e0118112. Available from: https:// dx.plos.org/10.1371/journal.pone.0118112.

24. Coelho A, Nogueira A, Soares S, Assis J, Pereira D, Bravo I, et al. TP53 Arg72Pro polymorphism is associated with increased overall survival but not response to therapy in Portuguese/ Caucasian patients with advanced cervical cancer. Oncology Letters [Internet]. 2018; 15 (5): 8165-71. Available from: http:// www.spandidos-publications.com/10.3892/ol.2018.8354/abstract.

25. Kodal JB, Vedel-Krogh S, Kobylecki CJ, Nordestgaard BG, Bojesen SE. TP53 Arg72Pro, mortality after cancer, and all-cause mortality in 105,200 individuals. Scientific Reports. 2017; 7 (1).

26. rs1042522 - Clinical Annotations [Internet]. Available from: https:// www.pharmgkb.org/variant/PA166155173/clinicalAnnotation.

27. Henríquez-HernándezLA, Murias-Rosales A, González-HernándezA, de León AC, Díaz-Chico N, Fernández-Pérez L. Distribution of TYMS, MTHFR, p53 and MDR1 gene polymorphisms in patients with breast cancer treated with neoadjuvant chemotherapy. Cancer Epidemiology. 2010; 34 (5): 634-8. DOl: 10.1016/j. canep.2010.06.013.

28. Huang ZH, Hua D, Li LH, Zhu J De. Prognostic role of p53 codon 72 polymorphism in gastric cancer patients treated with fluorouracil-based adjuvant chemotherapy. J Cancer Res Clin Oncol. 2008; 134 (10): 1129-34. DOl: 10.1007/s00432-008-0380-8.

29. Pouladi N, Abdolahi S, Farajzadeh D, Feizi MAH. Haplotype and linkage disequilibrium of TP53-WRAP53 locus in IranianAzeri women with breast cancer. Roemer K, editor. PLOS ONE [Internet]. 2019; 14 (8): e0220727. Available from: https://dx.plos. org/10.1371/journal.pone.0220727.

30. Voropaeva EN, Pospeloya TI, Voevoda MI, Mabimovv N. Changes in non-coding sequences of the tp53 gene in diffuse large b-cell lymphoma. Gematologiya i Transfusiologiya. 2018; 63 (3): 239-49. 